\title{
Chest wall tumor at relapse of multiple myeloma
}

\author{
*Tazi I, Nafil H, Mahmal L
}

Hematology Department, CHU Mohamed VI, Cadi Ayyad University, Marrakech, Morocco

African Heath Sciences 2013; 13(1): 160 - 161 http://dx.doi.org/10.4314/ahs.v13i1.22

\section{Case report}

We report the case of a 70-year-old Moroccan man who was diagnosed with stage IIIA IgA kappa multiple myeloma according to Durie and Salmon classification. He was an alcohol abuser and heavy smoker (2 packs per day). He was admitted to our department for thoracic pain, persistent and increasing. He also complained of mild shortness of breath and poor appetite. Initial physical examination was normal. Laboratory investigations showed a hemoglobin of $12 \mathrm{~g} / \mathrm{dL}, \mathrm{MCV}$ of $83 \mathrm{fL}$, white cell count of 3,900/ $\mathrm{L}$ and platelet of 174,000/ L.

The bleeding time and coagulation time were normal. Erythrocyte sedimentation rate was 100 $\mathrm{mm} / 1 \mathrm{~h}$ and C-reactive protein was $15 \mathrm{mg} / \mathrm{dL}$. A monoclonal spike was discovered in the betaglobulin of the serum. Immunoelectrophoresis identified the monoclonal component as IgA kappa and the level was $3.7 \mathrm{~g} / \mathrm{dl}$. A 24-hour specimen of urine was normal. The calcemia was normal. The bone marrow contained approximately 35\% plasma cells, with atypical aspects. X-ray examination showed lytic defect in cranial bone. The skeletal radiograph showed diffuse lytic lesions. Treatment with melphalan and prednisone (MP protocol) was started and bisphosphanate was administered regularly. After two cycles of MP therapy, the patient presented a chest wall tumor, dyspnea and cough (figure 1).

The WBC rose to $>30,000 \mathrm{cmm}$ with $40 \%$ circulating plasma cells and his inflammatory parameters were increased (C-reactive protein $71 \mathrm{mg} / \mathrm{L}$ ). Incisional biopsy was performed on the left chest wall and the histopathologic examination revealed an abundant number of atypical plasma cells demonstrating a myeloumatous etiology of the chest wall tumor (figure 2). Salvage chemotherapy

\footnotetext{
*Corresponding author:

Dr Tazi Illias

Department of Hematology

Cadi Ayyad University

Marrakech, Morocco

E-mail: Tazi_illias@hotmail.com
}

was performed with bortezomib, cyclophosphamide and dexamethasone. After the first cycle of chemotherapy, due to grade 3 asthenia, the patient could not receive consecutive cycles. He died four months later due to progression of multiple myeloma.

Multiple myeloma is a malignant tumor of plasmacytes most commonly seen in the bone marrow. The thorax can be invaded by myeloma, producing thoracic skeletal abnormalities, plasmacytoma, pulmonary infiltrates, and pleural effusion ${ }^{1}$. Recognition of the atypical plasma cells in fluids is critical for therapeutic and prognostic considerations as this finding portends a poor prognosis ${ }^{2}$. These patients are usually resistant to treatment in spite of aggressive chemo-radiotherapy.

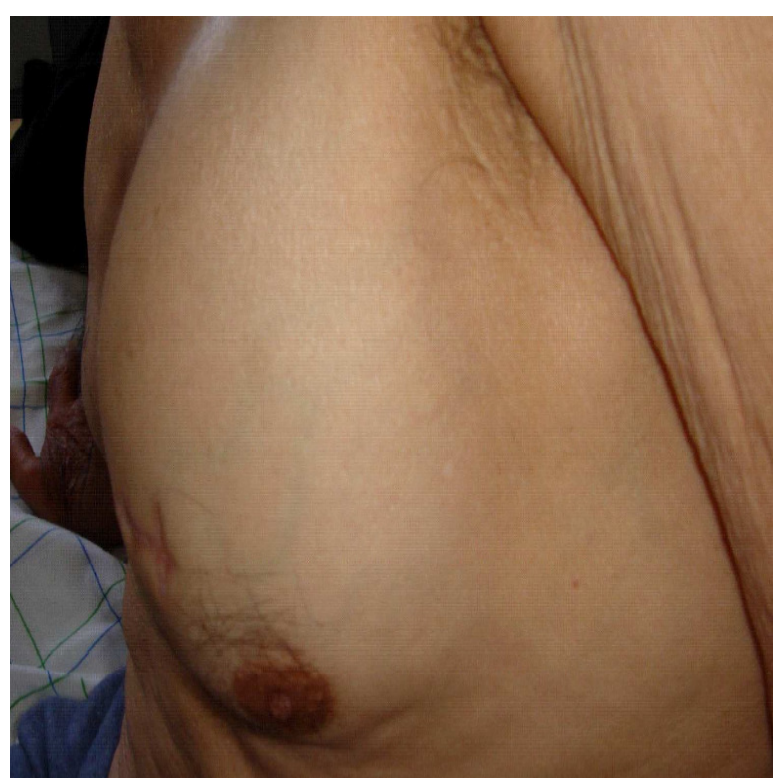

Figure 1: Chest wall tumor $722 \times 540 \mathrm{~mm}$ (72×72DPI) 


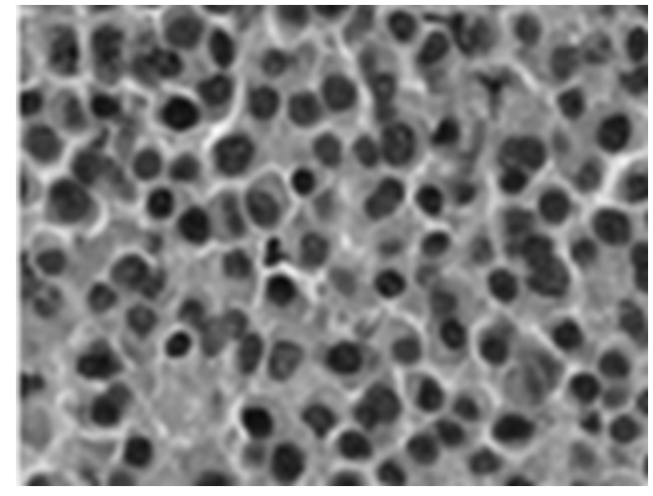

Figure 2: Histology of chest wall tumor showing abundant plasma cell

\section{References}

1. Kim YM, Lee KK, Oh HS, Park SK, Won JH et al Myelomatous effusion with poor response to chemotherapy. J Korean Med Sci 2000 Apr;15(2):243-6

2. Maachi M, Fellahi S, Diop ME, Francois T, Capeau J et al Pleural effusion as a first sign of Ig D lambda multiple myeloma. Ann Med Interne (Paris) 2005 Feb;154(1):70-2 